\title{
Denial of Service (DOS) Attack Identification As A Means To Be A Capable Guardian
}

\author{
RB Sularto ${ }^{*}$, Suryono ${ }^{2}$, Monica Puspa Dewi ${ }^{1}$, Kagirenza Alexis Fidele ${ }^{2}$ \\ ${ }^{1}$ Faculty of Law Diponegoro University \\ ${ }^{2}$ Master of Information System, School of Postgraduate Studies Diponegoro University
}

\begin{abstract}
The presence of computer program equipment intended to ensure the security of the operation of a business or company is surely an inevitability. This tool is a form of the presence of adequate supervision in overcoming deviant behavior (crime) in the midst of changes that occur in society. Routine Activitist Theory analysis has reminded that losses that occur in society such as financial chaos in the Indonesian banking sector can be traced through the identification of attacks on Denial of Service. As well as a combination of other factors in the form of identification is carried out on the motivated offender and the appropriate target (suitable target).
\end{abstract}

Keywords. Denial of Service Attack, Capable Guardian, Motivated Offender, Suitable Target

\section{Background}

When the corona virus emerged in December 2019, the world was shocked by the outbreak of a fast spreading pandemic was identified as a new emersion after decades of sleeping. A similar virus pandemic, previously known as the bird flu virus (SARS and MERS), attacks the respiratory tract of its sufferers.

The antivirus has not been discovered yet to deal with the plague, resulting the right response to be done traditionally by breaking the chain of virus spread through social and physical distancing methods. The method that proved to be right was carried out in the place where the virus first appeared, which is in Wuhan, Hubei Province, China. Through the lockdown method of the area, within a period of at least 14 days the virus that attacks the sufferers' respiration system was successfully inhibited.

Community self-isolation method carried out by various community groups do not necessarily reduce the occurrence of deviant acts or crimes by society members. This deviant behavior is either directly related to the spread of the virus or other deviant actions, including those related to the virtual world or cyberspace. This deviant behavior related to the cyber world is related to information systems involving a very broad spectrum related to business administration, management, customer relationship management, product

* Corresponding author: sulartorb@gmail.com 
development and marketing and others. These fields tend to be criminogenic in nature and open opportunities to obtain financial benefits from their use.

Kaspersky has just announced their latest report on DDoS attacks, which are associated with the increasing of community activities at home due to the Covid-19 corona virus pandemic. Quoted from Kaspersky's report on Tuesday (13/5/2020), DDoS (distributed denial-of-service) attacks experienced a significant increase during the first three months of 2020. This is because the perpetrators behind DDoS attacks took the opportunity when almost all activities including study, work, or leisure shift to online form [1]. Changes in community activities from real activity to virtual activity are not fully realized and anticipation of behavior changes that are not as fast as the spread of the virus has made many citizens become victims amid the outbreak of the Covid-19 pandemic.

An illustration of events having a very devastating impact in the economic sector, for instance, was what happened to banking sector in Indonesia. Bank Bukopin as a national private commercial bank, which at the end of 2019 and early 2020 was quite calm like other private banks, surprisingly, in mid-2020, there was a quite surprising incident since customers found it difficult to withdraw their funds from the bank and per day withdrawal was limited up to 25 million rupiah. The similar thing could also happen at branch bank offices. Meanwhile, at sub-branch offices, the withdrawal limit was much smaller. There was no formal explanation for the restriction, however, the "rush" condition in the Bukopin bank could clearly benefit certain parties.

\section{Problems Formulation}

IBM's internal records show that there has been an increase in cyber attacks of up to 6,000 percent in the last three months globally, in Indonesia, it occurred on online trading sites [4]. This phenomenon in the cyber world is certainly quite unsettling for the community. Potential losses due to cybercrime could reduce public interest in online activities amid the Covid 19 Pandemic.

Referring to this brief description, the problems related to the financial sector that can be furtherly discussed in this article are:

1) How to create the conditions so that society becomes the unsuitable target for cybercrime.

2) What steps that must be taken to provide adequate supervision in preventing and overcoming cyber crime

\section{Review of Literature}

When a question is asked, why in society there are various changes but crime still occurs, such a similar question can also be discussed, that is why crime still occurs when people do activities online in the midst of the Covid 19 pandemic?

To explain the crime that occurs in the midst of changes in society, Lawrence E. Cohen and Marcus Felson through the Rational Activitist Theory initially questioned why the crime rate in urban communities increased during the 1960s when common factors were blamed for it, namely such as poverty in economic conditions which had actually improved. Therefore, Cohen and Felson suggested an idea, that is crime is an event due to a certain condition and time and involves certain people and objects. They argued that a crime occurring involves least 3 elements in a certain space and time, namely: (1) an offender who had prepared to commit an offense, (2) a suitable target, for example a victim who was mistreated or an object to become the object of theft; and (3) an absence of capable guardian to prevent crime. 
The absence of these 3 factors has resulted in failure to prevent the crime that occurs. By referring to the scope of human ecological theories, Cohen and Felson suggested structural changes that occur as a pattern of routine activities in society affecting the crime rate influenced by time and space from these 3 elements. As the routine activities of a changing society, such as in terms of time and space, motivated behavior and adequate supervision, also change. In other words, opportunities to commit crimes and patterns of crime are a function of the routine activity patterns of society.

The routine patterns of society activities packed into the virtual world has caused the existence of this information is crucial to be noticed. In fact, many parties have made it a commodity in various matters related to people's lives. It is not an exaggeration if John Naisbitt said, "Information is an economic entity because it costs something to produce and because people are willing to pay for it". (P 36)

\section{Finding \& Discussion}

The deviant behavior that occurs, including in the context of changes in society, such as the COVID-19 pandemic, happens with specific conditions in the middle of the society itself. Crime that occurs as stated by Cohen and Felson, requires at least three elements, which are:

1) a motivated offender;

2) a suitable target;

3) the absence of capable guardian

Referring to the "rush" illustration of the financial sector in Indonesian society, that is, the "rush" of a national private bank, surely it can be seen in the possibility of obtaining financial benefits that can be obtained from selling additional shares at a lower price compared to the feasibility price of the assessment under normal conditions. Such condition, which is relatively more usable, certainly motivate certain parties to use them to obtain the financial benefits. Obtaining this goal can be done by attacking the server by sending massive data. Sending a flood of data to the target server results in network failure.

The second factor is the presence of a right target. Since the end of last year or around October 2019, the Financial Services Authority/Otoritas Jasa Keuangan (OJK) decided that this national private bank were under the guidance of a national which belonged to Bank Umum Milik Negara (BUMN), that is, Bank Negara Indonesia 1946 and then switched to Bank Rakyat Indonesia, in which the guidance was intended to assist the liquidity of the national private commercial bank. The disruption to the liquidity of national banks became even more pressing after the COVID-19 pandemic. The banking sector becomes quite vulnerable and its liquidity capacity is undeniably influenced by these conditions due to the pandemic. The ability of banks to provide liquidity is a requirement that Otoritas Jasa Keuangan is very concerned with and of course determines the sustainability of a bank accordingly. The condition of the bank oppressed by the covid 19 pandemic and the bank's ability bring in the condition, in which the bank has no other method to sustain life other than receiving additional capital so that its liquidity is maintained.

The presence of adequate supervision is a defining factor in protecting the society as user of bank services. The supervision cannot be left solely to the existing financial authority, that is Otoritas Jasa Keuangan. Offering additional shares to the public requires the optimal involvement of Badan Pengawasan Pasar Modal (Bapepam). Besides OJK's optimal role, the involvement of Bapepam is also required as well Lembaga Penjamin Simpanan (LPS), Perhimpunan Bank Nasional (Perbanas), Non-Governmental Organizations related to Consumer Protection such as YLKI and academics who can guard with academic considerations on steps taken by a certain party. Supervision carried out is not only in the real world of banking, but more importantly in virtual means determining 
the life of banking activities in society. Controlling factors in a company need to be based on ethics and morals of the businessmen in assigning their positions as controlling shareholder in a business.

Optimization of virtual supervision in banking activities, especially those that occur at national banks, needs to be implemented especially with the consideration that the "chaos" in the private banking world is a repetition of previous events. Previous chaos with Bank Bukopin were always linked to the state agency, Badan Urusan Logistik (Bulog). Even the Indonesian press illustrated that Bulog and Bukopin were like tree trunks with branches. Every time Bulog shoke, Bukopin also shoke [6]. The chaos in the era of the Covid 19 Pandemic was a financial chaos for Bukopin that had happened repeatedly. As a national bank whose business sector is related to the existence of micro and medium enterprises, naturally, the financial impact was perceived nationally. Even though foreign investor from South Korea, Kookmin Bank, had committed to maintain the liquidity of this national private commercial bank, the impact on the society was perceived especially among the small and medium enterprises sector.

Reinforcement of control or adequate supervision, especially in the virtual world, by strengthening the Denial of Service on the server, becomes a necessity to protect the society. Attacks against DoS are commonly found with attack identification level (TCP SYN, UDP and HTTP protocol) ranging from low (Q1), medium (Q2) and high (Q4) level. The most common identification attack is the overload of unwanted packet to the victim through varying numbers of packet requests, and the victim is unable to respond to the appropriate SYN-ACK. Eventually, an inappropriate response will result in an error for another party (for example an appraisal), resulting in an accurate assessment of a certain condition (a fair share price). Such condition like can indeed be expected to create misinformation in certain areas (stock prices).

\section{Conclusion}

The Covid 19 pandemic that occurred globally has changed society's behavior from real behavior to virtual behavior driven as a result of Physical and Social Distancing in the society. Changes in society's behavior do not drastically reduce the incidence of crime. One of the incidents that is quite vulnerable to occur is virtual behavior in the financial sector. Financial chaos at a national private bank was triggered by motivated offender, suitable target and absence of capable guardian. Supervision in the virtual world, especially eliminating the attack factor on Denial of Service (DoS) is a necessity.

Meanwhile, another step that must be taken to provide capable guardian in preventing and overcoming cybercrime in the financial world (banking and investment) is to encourage various parties (Banking, Bapepam, LPS, KPPU, Perbanas, YLKI, etc.) to increase awareness of financial life in Indonesia. The meaning of information is not only for the conditions that have changed human civilization from an industrial society to an information civilization, but also for understanding information as a commodity in society itself.

\section{References}

1. Liputan6.com downloaded on Monday 29 Juni 2020 at 14.26 WIB.

2. Maguire, Mike. Et al. (2003). The Oxford Handbook of Criminology. Oxford : Oxford University Press.

3. Naisbitt, John. 1982. Megatrend : Ten New Direction Transforming Our Lives. New York: Warner. 
4. Prasetya, Eko. Serangan Siber Meningkat Sejak Pandemi Covid 19. On www.merdeka.com Thursday, 18 June (2020).

5. Schmalleger, Frank. (2006). Criminology Today. New Jersey: Pearson Prentice Hall.

6. Tempo.com. "Sofyan Basir: No Contract With Bulog" 23 June 2003 Edition. 